\title{
EGFR NM_005228.3:c.2239_2256del18
}

National Cancer Institute

\section{Source}

National Cancer Institute. EGFR NM 005228.3:C.2239 2256de/18. NCI Thesaurus. Code C98560.

A deletion of 18 nucleotides from the coding sequence of the EGFR gene from position 2239 through 2256. 